\title{
Alfonso Corral* and Leen d'Haenens The construction of the Arab-Islamic issue in foreign news: Spanish newspaper coverage of the Egyptian revolution
}

https://doi.org/10.1515/commun-2019-0146

\begin{abstract}
The aim of this article is to analyze how the Spanish newspapers covered an international event such as the Egyptian spring from 2011 to 2013. From the perspective of the representation of Arab-Islamic issues, this study carries out a quantitative content analysis on the four reference newspapers in Spain (ABC, El Mundo, El País, and La Vanguardia) to find out whether there was an Islamophobic or Islamophilic treatment during the Egyptian revolution. The results of the 3,045 articles analyzed show that Spanish newspapers were remarkably interested in Egyptian events and that cultural discourses were not relevant in the coverage. However, it is necessary to specify these outcomes by newspaper, because each paper proposed its own take on the matter based on information provided by press agencies.
\end{abstract}

Keywords: Arab Spring, Islamophobia, Islamophilia, content analysis, Spanish press

\section{Introduction}

From a political and international-relations viewpoint, February 11, 2011 was destined to be a landmark date in the history of the Arab world. That day, Hosni Mubarak was forced to leave the presidency of Egypt after almost 30 years of rule. Owing to popular pressure, the country's military decided his time had come: Demonstrations had begun on January 25 with the firm intention to achieve more democracy, freedom, and social justice. As Rogan (2011) said, the overthrow of Mubarak must be understood as the most significant political event in the Middle East since the Islamic Revolution leading to the fall of the Shah of Iran in 1979.

*Corresponding author: Alfonso Corral, Migraciones, Interculturalidad y Desarrollo Humano (MIDH), Universidad San Jorge, E-Mail: acorral@usj.es.

Leen d'Haenens, Institute for Media Studies (IMS), KU Leuven,

E-Mail: leen.dhaenens@kuleuven.be. 
In addition, it should not be forgotten that hardliner Zine Eddin Ben Ali had undergone a similar fate in Tunisia a few weeks earlier. Although the Egyptian revolution did not occur only because of Tunisian events, they were the trigger. Previously, popular movements against corruption had taken place (Azaola Piazza, 2008). The most characteristic case was that of Khaled Said, who was beaten to death by the police in June 2010. That event and the encouragement of other notable opposition figures such as Mohamed El Baradei, Nobel Peace Prize winner in 2005, moved the Egyptians to achieve socio-political change (Al Aswany, 2011; Rogan, 2011; Rodríguez, 2012).

The 2011 riots served to overthrow Mubarak, but did not remove the army from power. Military commanders headed by Field Marshal Tantawi continued to lead the government through the transition that was to culminate in the June 2012 presidential elections. As in all the elections that had been held, the Freedom and Justice Party of Mohamed Mursi won in the second round. This party was dependent on the Muslim Brotherhood, an Islamist organization deeply rooted in Egyptian society. Just a year later, the army orchestrated a coup d'état to remove Mursi who was blamed for the political, economic, and social crisis that was ravaging the country. General al-Sisi had conspired to gain adepts such as the Coptic Christians, the youth of Tamarod, the Salafists of Al-Nur or relevant opponents such as El Baradei. In this context, Egypt's democracy seemed to vanish (Almodóvar, 2015; González del Miño, 2014).

After the removal of Mubarak in Egypt, a democratic wave rippled across other Arab countries such as Algeria, Libya, Yemen, Morocco, or Syria (Gelvin, 2013). However, each country's revolution followed its own path, which variously led to political change or repression and conflict (Soler i Lecha, 2013). Given this phenomenon's magnitude, some analysts and Western media dubbed it the 'Arab Spring' (Lynch, 2012). These events' relevance has not gone unnoticed in academic circles. At a communicative or journalistic level, these revolutions have been studied by comparing TV broadcasts (Elena, 2015; Fornaciari, 2011), newspapers (Alasuutari, Qadir, and Creutz, 2013; Al Maskati, 2012; Corral-García and Fernández Romero, 2015; Piquer Martí, 2015), or a variety of media outlets (Lim, 2013). The focus of these studies was on journalistic genres (Golan, 2013), social and new media (Cottle, 2011; Halverson, Ruston, and Trethewey, 2013; Rane and Salem, 2011), the slogans or pictures used in the demonstrations (Clarke, 2013; Córdoba Hernández, 2015), or the quality of the Arabic translations in the newspaper coverage (Hernández Guerrero, 2012). Theoretically, most of these studies were grounded in the agenda-setting and framing traditions.

This article aims to continue this research strand, digging deeper into the construction of the Arab-Islamic issues through the perspective of foreign news and cultural narratives. We prefer the term Arab-Islamic to recognize the features 
of a cultural tradition clearly rooted in the Middle East and North Africa (MENA region) with a universal religion. In fact, "Muslims are very diverse in terms of their cultures, languages, ethnicities, nationalities, geographical distribution, histories, education levels, economic development and political experiences" (Rane, Ewart, and Martinkus, 2014). Furthermore, 80\% of the world's Muslim population is not Arab (Serrano, 2009).

As our literature review shows, certain discursive Western standards about Islam, Muslims, and Arabs generate clear representational patterns and stereotypes. Rane, Ewart, and Martinkus (2014) point out that for most of the current generation of Western correspondents in the MENA region, the Arab uprisings were their first reporting experience. In other words, for the first time since the 9/11 attacks against the United States, the Western media were not perceived as exponents of US policy in the region. It should be remembered that the previous decade was marked by the wars in Afghanistan and Iraq-that is, focus on the MENA region was mostly informed by the so-called 'war on terror'.

Likewise, it is also relevant to know to what extent the classical characterizations of the Arab-Islamic issue were in Spanish newspapers. As a transnational event, the Egyptian Spring has nothing in common with three of the usual themes in the domestic coverage of Arab-Islamic matters-religion, terrorism, and migration. Indeed, these Arab revolutions aligned perfectly with Western ideas and values such as freedom, human rights, justice, democracy, dignity, equality, future, or modernity (Castells, 2012; Gelvin, 2013; Hafez, 2016).

In this sense, some studies have confirmed that newspaper coverage about Islam differs depending on whether this issue is treated as a domestic or a foreign issue (Ahmed and Matthes, 2016; Anderson, 2015; d'Haenens and Bink, 2006; Hafez, 2000; Ibrahim, 2010; Ichau and d'Haenens, 2016; López, Otero, Pardo, and Vicente, 2010; Mertens and d'Haenens, 2013; Poole, 2002; Powell, 2011; Richardson, 2004; Shaw, 2012). This has been defined by Frissen et al. (2017, p. 143) as the "history of misrepresenting and marginalizing Islam and Muslims". After reviewing reporting about German, Italian, or Dutch cases, Cesari (2011, p. 33) points at "a tendency to mix foreign and domestic Islam together, thus extending the entire trope of politically radical Islam to immigrant Muslim populations". Indistinctly, news about Islam in the post-9/11 world could be synthesized by these five dominant frames: "Islam is a monolithic religion, Islam is a uniquely sexist religion, the 'Muslim mind' is incapable of rationality and science, Islam is inherently violent, and the West spreads democracy, whereas Islam spawns terrorism" (Kumar, 2010, p. 272).

Despite not being a Western country, the case of China's media treatment of 'national Islam' and 'foreign Islam' is especially illustrative (Luqiu and Young, 2018). This research concludes that international press agencies of the West (i.e., 
Reuters and Associated Press) generally provide their own agendas and frames, an idea which is reaffirmed by other authors (Drago, 1994; Shelton, Cleven, and Hoffman, 2013; Valenzuela, 2013). Furthermore, media coverage of international affairs related to the MENA region has created categories about 'right or good Islam' and 'bad Islam', that is, between heroes/allies and 'evil'/enemies (Kumar, 2018; Powell, 2011). This binary aspect may also be relevant when one looks at the main features of the Egyptian revolution.

One of our goals is to determine whether the Spanish newspaper coverage of the Egyptian revolution was consistent from the first demonstrations against Mubarak until the end of 2013, a time when Egypt's political situation seemed to have returned to its starting point with the military seizing all powers. Specifically, this research reviews the key events of the Egyptian revolution through a quantitative content analysis which will allow comparisons to be made and certain patterns to be drawn about the coverage and cultural narratives of each newspaper under study.

\section{Islam, the Arabs, Egypt, and Spain: From Orientalism to Islamophobia}

Edward Said's Orientalism (1978) may have been one of the first compilations of Western representations of Arabs and Muslims as evil and depraved human beings, licentious and barbaric, ignorant and stupid, dirty and inferior, monstrous and ugly, fanatical and violent. Such characterization was consistent during the colonization period and marks an essential feature of Orientalism the Western discourse/thought being intent on dominating and shaping Eastern lands and populations. Such representations were mostly contrived and upheld by merchants, travelers, diplomats, colonial administrators, novelists, historians, soldiers, etc. (Said, 1978, 1981).

In this sense, Spain is the Western country with the longest and deepest tradition of contact with the Arab world (González Alcantud, 2002). This started well before the crusades and, of course, colonialism: The presence of Islam and Arabs in the Iberian Peninsula dates back to the eighth century, when they came to Gibraltar in 711 (Martín Corrales, 2004). This created a network of contacts and relationships that live on to this day. However, as a consequence of the Spanish Christian Kingdom's victory after eight centuries of Reconquista and the eviction of Muslims in 1492, Islam was never well regarded by historians. It was not until the advent of the romantic movement that the Arab-Islamic identity and its contributions to the national cultural heritage were recognized in Spain (López García, 2013). 
The end of the Reconquista coincided with the beginning of the Castilian expansion along the North African border (Melilla, Oran, Tunisia, Tripoli, etc.) and its inevitable confrontation with the Western expansionism of the Ottoman Empire. The enmity maintained by both empires created a state of chronic confrontation between both sides throughout the $16^{\text {th }}, 17^{\text {th }}$, and $18^{\text {th }}$ centuries, before they finally reached a degree of entente (Martín Corrales, 2004). This did not last long, however, Spain's relationship with the Arab-Islamic world being a history of ups and downs, of periods of war and peace, trade and conflict, until Morocco’s independence in 1956 (González Alcantud, 2002; López García, 2014).

Egypt and Spain provide an example of a history of constant commercial, political, cultural, and religious interactions. In recent times, this is reflected, for example, in the creation of the Spanish Embassy in Cairo in 1949, in the foundation of the Egyptian Institute of Islamic Studies in Madrid in 1950, or in the signing of the Cultural Treaty in 1952. The Franco regime was always more inclined towards the Arab states on the Palestinian issue, favoring relations and mutual understanding. In fact, the arrival of Spanish democracy in the seventies reinforced the links that have extended until the present (Algora Weber, 2003, 2011; Awad, 2006; Azaola Piazza and González González, 2012).

From an international perspective, several Arab-Islamic events that happened, took part in the second half of the twentieth century (i.e., the Palestinian issue, the oil crisis, the Iranian Revolution, or the first Gulf War) became familiar to the Western and Spanish publics due to the development of global media (Ahmed and Matthes, 2016; Alba Rico, 2015; Córdoba Hernández, 2011; Ibrahim, 2010; Kumar, 2010; Said, 1981; Sardar, 2009). Gradually, religious fanaticism and fundamentalism acquired relevance in the media representations of Islam, whose patterns did not differ all that much from those of the times of the crusades (Sardar, 2009). Notwithstanding, it was not until the disintegration of the Soviet Union and the end of the Cold War that Islam was truly seen as the new enemy. At that moment, Lewis's (1990) and Huntington's (1993) ideas about a clash of civilizations were gaining traction in the political, media, and social spheres. According to this theory, post-Cold War world conflicts no longer confront ideologies but identities, and Islam is the enemy of the West because of history and perceived value discrepancies (Huntington, 1996).

On an endogenous level, two other circumstances further obscured the Arab-Islamic issue. First, starting in the same second half of the twentieth century, the presence of Islam and Arabs in the West has been expanded by migratory movements (Modood, Triandafyllidou, and Zapata-Barrero, 2006). Second, the $21^{\text {st }}$ century began with the 9/11 attacks against the United States, ushering in a new phase of international terrorism that targeted Western countries (bombings 
in New York, Madrid, London, etc.), a definite turning point. In politics, it motivated the new 'war on terror' and the invasions of Afghanistan and Iraq (Kumar, 2010; Reza, 2011; Segura, 2004). In addition, 'Islamophobia' began to take root in Western societies through hate crimes and hate speech (Allen, 2010; Rana, 2007). This also was a definite turning point in the media discourse on Islam, Arabs, and Muslims. After the 9/11 attacks, the frames about 'external' Arab-Islamic issues were more linked to violence, bloodiness, suicide, radicalism, rage, barbarity, sexism, despotism, or fundamentalism (Bensalah, 2006; Ibrahim, 2010; Khader, 2016; Kumar, 2010; Martin and Phelan, 2002).

In short, over the last three decades, orientalism was replaced by 'Islamophobia' in the public sphere (Alba Rico, 2015; Bravo López, 2011; Halliday, 1999; Rana, 2006). This controversial concept (which opponents point out is designed to forbid criticism of a religion as separate from its practitioners and has been a primary weapon in the communications arsenal of Islamist enemies of the secular West) describes a form of religious intolerance or cultural racism-or a mix of both-that reflects "a hostile attitude towards Islam and Muslims based on the image of Islam as an enemy, as a threat to 'our' well-being and even to 'our' survival” (Bravo López, 2011, p. 569). Due to history and vicinity, 'Islamophobia' in Spain also involves a certain Maurophobia, that means hostility, alienation, or hatred towards the Moors, who come from North Africa or the Maghreb (González Alcantud, 2002). Even today, in Spain it is common to use the pejorative term moro to designate Muslims in general and Moroccans in particular. However, this notion includes many other present and past origins such as Saracens, Berbers, Turks, Arabs, Ottomans, Persians, etc. In other words, being Muslim in Spain implies being 'Moorish' (Martín Corrales, 2004). Consequently, this Maurophobia is a form of Arabophobia (Khader, 2016).

\section{Arab-Islamic discourses, clichés, and archetypes in Spanish media narratives}

Despite the fact that Spanish newsrooms have journalists and correspondents who are experts in the Arab and Muslim world (León, 2005), some studies have pointed out that Spanish media use the same patterns of representation that prevail in the rest of the Western world (Beck, 2012; Bodas Barea and Drago, 1994; Casani Herranz, 2016; Khader, 2016). Nonetheless, this article will strive to describe the specificities of the Spanish case with respect to the main themes, discourses, stereotypes, and archetypes of the Arab-Islamic issue.

First, the traditional Spanish agenda about the Arab-Islamic issue has usually focused on matters such as immigration, relations with Morocco, the question of 
the Western Sahara, the border problems relating to Ceuta and Melilla, and other recurring topics such as the Middle East wars, controversies, tragedies, killings, and the Palestinian-Israeli conflict, etc. (Corpas, 2010; Martín Corrales, 2004). In the last decades, this has included terrorism, Islamism, and the Arab revolutions (López García, 2014). Overall, the Spanish media agenda covers four main themes: 1) the perception of Morocco (immigration, diplomacy, Western Sahara, Ceuta and Melilla); 2) the representation of difference/cultural clash (the situation of women, the veil issue, a purported 'clash of civilizations'); 3) the construction of bridges between cultures (Alliance of Civilizations, Union for the Mediterranean, economic affairs); and 4) terrorism as a subject par excellence (López et al., 2010). In this sense, there is a mixture of over-information and silencing or disinformation, because while some themes appear constantly (immigration, terrorism, women), others are never covered, that is, culture, inequalities, corruption (Khader, 2016; Piquer Martí, 2015; Valenzuela, 2013).

Second, the 'othering' of Islam, Muslims, and Arabs is based on notions such as morbidity, magnificence, sensationalism, Islamization, dramatization, generalization, caricature, demonization, stigmatization, superficiality, and simplification (Beck, 2012; Bensalah, 2006; Louassini, 2003; Ortega Marín, 1994; Piquer Martí, 2015; Taibi and El-Madkouri, 2006). This slant is completed by other practices such as selective and biased use of pictures, headlines, testimonies, vocabulary, translations from Arabic, metaphors, historical accounts, etc. (El-Madkouri, 2006; Hafez, 2016; Luyendijk, 2013; Taibi and El-Madkouri, 2006; Van Dijk, 2008). One can also think of discourses about Western superiority, the Islamic threat, Islamic invasion, or the incompatibility of Islam and democracy (Bensalah, 2006; El-Madkouri, 2006; Khader, 2016; Tortosa, 1999). In the words of Alba Rico (2015), these construction mechanisms of the manipulable and exterminable 'other' are reduced to three: the other as a unit, the other as a negative unit, the other as an inassimilable negative unit.

Third, the Spanish social imaginary is rich in clichés and stereotypes that are sometimes reproduced by the media. It is made up of images, ideas, or symbols such as veils, burqas, beards, polygamy, mosques, turbans, clitoral ablation, ignorance, backwardness, stoning, violence, fanaticism, savagery, lust, sloth, prayer, invading, delinquency, or machismo (Beck, 2012; Martín Corrales, 2004; Martín Muñoz, 2010; Taibi and El-Madkouri, 2006; Valenzuela, 2013).

Finally, regarding archetypes, Balta (1994) described the four characters in which the media represents people living in the Arab-Islamic world: the terrorist; the unskilled and uneducated immigrant worker; the wealthy emir of the Persian Gulf; and the fanatical fundamentalist born out of the Iranian revolution. However, this categorization does not include two profiles that have gained attention over time: the political leader and the westernized citizen. The 
first one appears quite often in the media as moderate or extremist, conservative or modern, fundamentalist or secular, Europeanized or non-Europeanized (Abdelkefi, 1994). Indeed, it is interesting to see how the representation of some leaders changes depending on media, events, and circumstances (García Gordillo, 2004). The second one is more recent. It describes a long-awaited prototype and represents the conscious, educated, active, internationally-minded, and social-media savvy young person who wants to live the Western way of life (Zahedi, 2014). This is the 'good Muslim', whether living in the West or in the Arab-Islamic world (Martín Muñoz, 2007). If there is another type of humanity that is not represented in these six profiles, it might be homo islamicus-or araboislamicus-, a retrograde and violent human being, a threatening reverberation that arises from the combination of hostility and reductionism (Martín Muñoz, 2010).

As Hafez (2016) warns, it is increasingly difficult to find such representations in the media. On the contrary, Hafez's 'new Islamophobia' is more illustrative, sophisticated, subliminal, or latent. It is politically correct and avoids the classic stereotypes or generalizations but is supported by the configuration of agendas, themes, and graphic compositions.

\section{Method and hypotheses}

We looked at ABC, El Mundo, El País, and La Vanguardia, Spain's four newspapers of record (Armañanzas and Díaz Noci, 1996; Reig, 2000). Ideologically, $A B C$ and La Vanguardia are linked to Catholicism and conservative values, although the former is associated with Spanish traditionalism and the latter with the Catalan bourgeoisie. El Pais is considered as progressive, social democratic, and moderate, while El Mundo is also seen as progressive but with a more combative and critical bent as well as having more centrist sensibilities (Barrera, 1995; Canel, 1999; Durán, 2019; Jiménez-Yáñez, 2019; López et al., 2010; Moreno Espinosa, 2000; Zugasti, 2007).

Through the chronologies established by the European Institute of the Mediterranean, we defined the 48 moments of high informative interest for the Egyptian revolution between 2011 and 2013. The extent of these key moments could vary from a particular day-that is, the announcement of elections, for example-to wider intervals such as demonstrations, conflicts, or electoral processes. We also chose to include the day before and the three days after the date or interval selected in an effort to ensure predictability and monitoring of the event itself. 
Afterwards, the journalistic articles were compiled by manually reviewing the printed editions and focusing exclusively on headlines or the first reading-level elements (lead, picture captions, highlights). As a result, a total of 3,045 newspaper articles referring to the events in Egypt, in particular, or the so-called Arab Spring in general were retrieved. Subsequently, a set of generic (genre, size, authorship, data) and more specific (tone, theme, actors, keywords) variables was applied to examine the Spanish coverage as part of a quantitative content analysis. Previously, a pre-test had been carried out to test the usability of our coding instrument. In this sense, according to our pre-test findings and the literature review, the hypotheses that we seek to confirm or refute are:

$\mathrm{H}_{1}$ : The Spanish newspapers provided an in-depth and sustained coverage of the Egyptian revolution to such an extent that it seemed more like a domestic issue than an international one.

$\mathrm{H}_{2}$ : The Egyptian revolution changed the media coverage of the Arab-Islamic issue regarding topics, discourses, and archetypes, as indicated in the literature review.

$\mathrm{H}_{3}$ : Although it is very possible that both Islam and Islamism had an excessive weight in the coverage, there was hardly any 'Islamophobic' discourse, since the Egyptian revolution had nothing in common with classical Western clichés about Islam such as terrorism or immigration.

$\mathrm{H}_{4}$ : At certain points of the Egyptian revolution, the Spanish press produced 'Islamophilic' discourse.

$\mathrm{H}_{5}$ : The conservative or Christian-oriented press is more negative and more concerned with Islamic religious issues than the progressive press. In fact, if Islamophobic narratives appear, they are also more evident in the former case.

In this study, two specific categories have been created to recognize the presence of 'Islamophobic' and 'Islamophilic' discourses. First, departing from the eight closed views of the Runnymede Trust (1997), the 'Islamophobic' narrative refers to mentions subordinated to those discourses or feelings-explicit or implicitrooted in generalizations, stereotypes, prejudices, or fears towards Islam, Muslims, Arabs, and everything related to them that may constitute a violation of human rights and a threat to social cohesion (Ramberg, 2004). Second, focusing on the eight open visions of the Runnymede Trust (1997), the 'Islamophilic' narrative assumes respectful, cordial, integrating, conciliatory, universal, or humanist discourses-explicit or implicit-, whose purpose is understanding, friendship, alliance, equality, or coexistence with Islam, Muslims, or Arabs and everything related to them. In other words, 'Islamophilia' counters racism and discrimination against Islam, Muslims, and Arabs (Karvala, 2016). 
The difference between the open and closed views of Islam is that the former views refer to legitimate criticism and disagreement, the latter respond to unfounded prejudice or hostility (Elahi and Khan, 2017). For example, an Islamophobic argument might be that Arab-Islamic societies are not compatible with democracy, while an Islamophilic approach might be to argue that these communities share the same aspirations with Western ones: life, freedom, and the desire for happiness (Valenzuela, 2013).

Finally, as our purpose was to quantify not only presence or absence, but also relevance, we established a hierarchy based on three values. 'High' ranking recognizes persistent notions reflected in headlines or the first reading-level elements. 'Medium' ranking consists of evident and consistent mentions. Lastly, 'Low' ranking only pertains to occasional or distant mentions considering the priority elements of the articles.

\section{Results}

The newspaper distribution of the 3,045 articles reveals that the most extensive coverage was that of La Vanguardia, with 906 articles (29.7\%), although the other newspapers were hot on its heels: 779 articles by El País (25.6\%), 725 articles by El Mundo (23.8\%), and 635 articles by ABC (20.9\%). La Vanguardia's high score is explained by its unusual journalistic practice: 'photo-news', in which a picture is equivalent to a news article as it includes a headline and a short text.

\section{The timeline of the Egyptian revolution}

From a time-based viewpoint, the results reflect our evidence concerning the relevance of the Egyptian socio-political change in Spanish newspapers. Figure 1 shows the daily distribution of the relevant news articles, whereby three specific moments stand out: the rebellion that removed Mubarak (January and February 2011), the coup d'état that deposed Islamist president Mohamed Morsi (July 2013), and the socio-political consequences of this coup (August 2013). In addition, only one of the 48 moments of high informative interest that define our sample did not appear in the coverage: the beginning of Tamarod's signature drive (Tamarod is an Egyptian grassroots movement that demanded Morsi's resignation). This event took place between 2 and 6 May 2013 and was decisive for the future of the Egyptian revolution. 


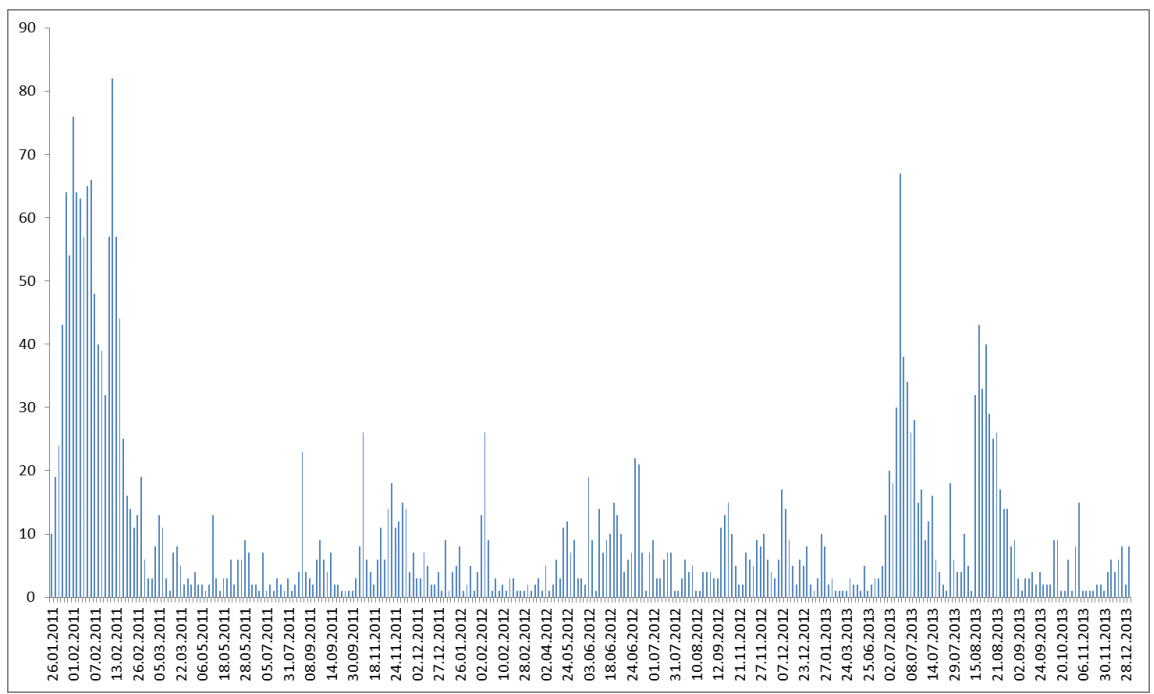

Figure 1: Daily coverage in Spanish newspapers (total).

Besides, the three years analyzed were divided into four large blocks for future comparisons: the fall of Mubarak (January 24, 2011 - February 16, 2011, 34.3\%), the military transition (February 24, 2011 - February 25, 2012, 19.8\%), the elections and the Morsi government (February 28, 2012 - April 14, 2013, 18.6\%), and the coup (May 2, 2013 - December 29, 2013, 27.3\%). It is quite significant that the shortest period yielded the most results, demonstrating considerable media interest in the wave of change in Egypt and the Arab world.

\section{Formal details of the Spanish newspapers' coverage}

Another physical aspect that reinforces the attention of the Spanish newspapers is the prominence of the front page ( $8.8 \%)$, the third most relevant section after international news (66.3\%) and opinion pages (16.5\%). A strikingly low number of articles came from press agencies (4.6\%). Of course, the most common authorship consisted of editors (24.4\%), followed by parachuting journalists $(23.8 \%)$, columnists (17.8\%), and correspondents (9.8\%). However, it is necessary to stress that these data are slanted because El País never mentions correspondents and rarely parachute journalists. Indeed, when the dateline is provided $(\mathrm{N}=1681$ articles), Egypt appears in 66.2\%, a considerable distance from Spain (10.2\%), other Arab (7.1\%) or European countries (5.2\%), the United States (5.2\%), and Israel (3.1\%). 
The most frequent journalistic genres were news reports (45.6\%), columns or opinion articles (18.5\%), feature articles (12.1\%), photo-news (10.6\%), and editorials (4.2\%). In spite of these results, Requena (2012) thinks the coverage lacked analysis and contextualization, which explains the surprising large portion of the public opinion when the Islamists reached the presidency. In her opinion, there are fewer expert journalists on the ground and more victims of propaganda on both sides.

\section{Main themes and actors}

There were only eight matters whose frequency was higher than $4 \%$ of the total; the ones standing out being international political issues (15.2\%), conflicts (13.8\%), and domestic politics (12.1\%). Less relevant were the Arab Spring as a theme (8.9\%), demonstrations (8.6\%), Islamism (6.1\%), electoral matters (4.9\%), and judicial affairs (4.6\%). Consequently, other issues such as religion (2.8\%), economy (2.6\%), and tourism (1.6\%) were barely touched on in the articles. In sum, these outcomes suggest that the most popular issues were always linked to politics.

In terms of tone, even though all the newspapers offered a negative interpretation in their Egyptian coverage, La Vanguardia is the closest to $50 \%$ (47.6\%). Conversely, the most negative or pessimistic was $A B C$, since it only offered positive treatment in approximately one out of every three cases $(33.6 \%)$, while $E l$ Mundo (43\%) and El País (41.2\%) straddled the line. In fact, when interpreting the Egyptian socio-political landscape, newspapers always presented a negative scenario (94.9\%), with El País offering the most critical view. As we can see, these findings are not related to the ideological inclinations of each newspaper, because there are no regular patterns in the coverage in religious (e.g., Catholic or not) or political (left, right, liberal, etc.) terms.

Furthermore, the papers presented the following as the main characters of the Egyptian revolution: the army (12\%), Hosni Mubarak (11.3\%), the Muslim Brotherhood (11.3\%), Mohamed Morsi (9.3\%), and Egyptian society at large $(8.5 \%)$. The remaining frequencies are distributed among many other actors such as the United States and their representatives (6.4\%), the Copts (2.9\%), the European Union or European governments (2.2\%), Israel and its representatives (2.1\%), political opponent Mohamed El Baradei (1.8\%), journalists and the media (1.7\%), Field Marshal Tantawi (1.1\%), and General al-Sisi (1\%). 


\section{Keywords and picture coverage}

The frequency of some concepts, personalities, groups, countries, or institutions allowed us to measure the presence of what we called clichés or keywords. Table 1 confirms that Hosni Mubarak, the Muslim Brotherhood, the army, and democracy are the only elements that were mentioned in more than half of the articles analyzed. Nevertheless, it reflects differences between newspapers. For instance, regarding democracy, there were 15 percentage points between El País and La Vanguardia. Additionally, the table highlights the large number of references to Islam (34.4\%), Israel (20.6\%), and the Copts (12.7\%), while reflecting the importance of these factors in the Spanish coverage of the Egyptian revolution compared to the Arab League (3.4\%). In the case of the Copts, the data illustrate that their presence was more common in the Christian-oriented press, that is, $A B C$ and La Vanguardia.

Table 1: Keywords or cliché frequencies in the coverage $(N=3,045)$ (in percentages).

\begin{tabular}{lrrrrr}
\hline References to & ABC & EM & EP & LV & $\begin{array}{c}\text { Total press } \\
\text { (means) }\end{array}$ \\
\hline Hosni Mubarak & 57.2 & 64.3 & 64.7 & 54.5 & $60.0^{\star \star \star}$ \\
Muslim Brotherhood (and the Freedom and & 56.7 & 53.4 & 60.8 & 51.4 & $55.4^{\star \star \star}$ \\
Justice Party) & & & & & \\
Army \& Supreme Council of the Armed Forces (SCAF) & 53.2 & 51.9 & 59.7 & 50.4 & $53.7^{\star \star \star}$ \\
Democracy & 49.8 & 51.2 & 61.7 & 45.5 & $51.9^{\star \star \star}$ \\
Islam as religion & 35.1 & 34.8 & 37.1 & 31.5 & 34.4 \\
Mohamed Morsi & 34.5 & 33.2 & 37.4 & 30.7 & $33.8^{\star}$ \\
Islamism/political options linked with Islam & 27.7 & 25.7 & 29.4 & 25.9 & 27.1 \\
(i. e., Salafism) & & & & & \\
Israel & 17.8 & 18.6 & 23.7 & 21.5 & $20.6 *$ \\
Coup d'état & 21.3 & 18.2 & 23.0 & 17.1 & $19.7^{\star \star}$ \\
The Copts & 15.4 & 12.1 & 11.0 & 12.6 & 12.7 \\
Mohamed El Baradei & 9.9 & 13.5 & 10.7 & 9.7 & 10.9 \\
The Arab League & 2.8 & 4.6 & 3.2 & 3.1 & 3.4 \\
\hline
\end{tabular}

Legend: ABC ( $A B C)$, EM (El Mundo), EP (El País), LV (La Vanguardia).

Note $:{ }^{*}=\mathrm{p} \leq .05 ;{ }^{* *}=\mathrm{p} \leq .01 ;{ }^{* \star *}=\mathrm{p} \leq .001$

This section closes with a brief review of the graphic coverage of the Egyptian revolution. First, pictures were found in almost half of the articles (49.7\%), and the themes reflected in them were usually conflictive and warlike (29.5\%), linked to demonstrations $(29.1 \%)$ or political and electoral contexts $(28.3 \%)$. 
Therefore, the coverage left no scope for issues such as religion (5.4\%), culture $(2.1 \%)$, or tourism $(1.7 \%)$, for instance. Finally, it is worth noting that the main image only reflected the classic stereotypes in $5.3 \%$ of cases. This is an especially significant fact since the results are similar for all newspapers: El País (6.4\%), ABC (5.8\%), El Mundo, (4.9\%) and La Vanguardia (4.2\%). Thus, there was no over-representation of Islamic symbols, no attempt to emphasize notions such as barbarity, destruction or fanaticism in the pictorial coverage. The trouble is that all these stereotypes appear when there is no relationship to the issues covered in the news (Taibi and El-Madkouri, 2006), which is a problem since images have great persuasive power, remaining in the minds of the readers for a long time (Bensalah, 2006).

\section{'Islamophilia' and 'Islamophobia'}

The last aspect considered is the frequency of cultural narratives in the Spanish coverage. In this sense, it is necessary to point out that neither the 'Islamophobic' nor the 'Islamophilic' category had a significant impact (14.1\% and $12.1 \%$, respectively). In both cases, these standards were much lower than we could have imagined. However, there are substantial nuances between the newspapers under study. Regarding 'Islamophobia', the overall results were highest with ABC (23.1\%), in contrast to El Mundo (15.3\%), La Vanguardia (11\%), and El País (9\%). In the case of 'Islamophilia', progressive newspapers El País (16.8\%) and El Mundo (11.2\%) outperformed the Christian-oriented press ABC (10.6\%) and $L a$ Vanguardia (9.9\%).

Subsequently, as Table 2 shows, the hierarchy of both categories inside the articles demonstrates that, on the one hand, 'Islamophobia' appeared in the least perceptible places, that is, far from the first-level reading elements (55.9\%). The case of El País stands out, with almost $95 \%$ when aggregating the low and medium rankings. By contrast, the rest of the newspapers did exhibit 'Islamophobia' in high-ranking elements-headlines, captions, and so on: mostly La Vanguardia (30\%) and $A B C(29.3 \%)$. On the other hand, 'Islamophilia' was exhibited more homogeneously among the three possible options. Despite this fact, El País only reaches $32.1 \%$ in low ranking, while the other newspapers exceed $40 \%$. Moreover, unlike the 'Islamophobic' narrative, El País carried 'Islamophilia' to its first-level elements (32.8\%), more than 10 percentage points higher than La Vanguardia (21.1\%), which introduced it in less implicit ways in most cases (43.3\%). 
Table 2: 'Islamophobic' and 'Islamophilic' category hierarchy (in percentages).

\begin{tabular}{lllllllllll}
\hline Rank & \multicolumn{1}{l}{ ABC } & \multicolumn{2}{l}{ EM } & \multicolumn{2}{c}{ EP } & \multicolumn{2}{l}{ LV } & \multicolumn{2}{c}{ Total press } \\
\cline { 2 - 11 } & .phobia & .philia & .phobia & .philia & .phobia & .philia & .phobia & .philia & .phobia & .philia \\
\hline Low & 49.6 & 40.3 & 61.3 & 42.0 & 61.4 & 32.1 & 55.0 & 43.3 & 55.9 & 38.4 \\
Medium & 21.1 & 31.3 & 16.2 & 28.4 & 32.9 & 35.1 & 15.0 & 35.6 & 20.3 & 33.1 \\
High & 29.3 & 28.4 & 22.5 & 29.6 & 5.7 & 32.8 & 30.0 & 21.1 & 23.8 & 28.5 \\
\hline
\end{tabular}

Incidentally, from a temporary viewpoint, if 'Islamophobia' was more present during the coup d'état and the events that followed (31.3\%), 'Islamophilia' was more palpable during the fall of Mubarak (49.6\%). This confirms the hypothesis that prejudiced discourses increased when the chances of achieving true democracy in Egypt vanished. Conversely, when the Egyptians revolted against Mubarak demanding freedom, justice and democracy, the Spanish newspapers were more Islamophilic. Surely, in January and February 2011, the Western and Arab-Islamic worlds were closer than ever before, at least in terms of values, and that had repercussions in the media. In that phase, religion was never a frontline issue. As Table 3 shows, 'Islamophobia' was most evident during the presidential elections and Morsi's Islamist tenure for El País (42.9\%) as well as during the coup and subsequent events for La Vanguardia (40\%). Correspondingly, El Mundo's $21.1 \%$ with respect to the 'Islamophilic' discourse during the 'Islamist period' must be highlighted.

Table 3: 'Islamophobic' and 'Islamophilic' narratives in the four stages of the Egyptian revolution (in percentages).

\begin{tabular}{|c|c|c|c|c|c|c|c|c|c|c|}
\hline \multirow{2}{*}{ Stage } & \multicolumn{2}{|l|}{$A B C$} & \multicolumn{2}{|l|}{ EM } & \multicolumn{2}{|l|}{ EP } & \multicolumn{2}{|l|}{ LV } & \multicolumn{2}{|c|}{ Total press } \\
\hline & .phob & a .philia & .phobi & a .philia & .phob & a .philia & .phob & a.philia & .phob & .philia \\
\hline $\begin{array}{l}1 \text { The Fall of } \\
\text { Mubarak }\end{array}$ & 24.5 & 47.8 & 26.2 & 40.7 & 21.4 & 56.5 & 36.0 & 48.9 & 27.1 & 49.6 \\
\hline $\begin{array}{l}2 \text { The Military } \\
\text { transition }\end{array}$ & 21.1 & 26.9 & 19.8 & 29.6 & 8.6 & 20.6 & 12.0 & 26.7 & 16.6 & 25.2 \\
\hline 3 The Morsi era & 27.2 & 9.0 & 22.5 & 21.1 & 42.9 & 9.2 & 12.0 & 12.2 & 25.0 & 12.5 \\
\hline 4 The coup & 27.2 & 16.3 & 31.5 & 8.6 & 27.1 & 13.7 & 40.0 & 12.2 & 31.3 & 12.7 \\
\hline
\end{tabular}

Considering some physical features of the articles, the columnists were the authors who supported both narratives the most (46.6\% .philia, 35\% .phobia). Therefore, the most common type of text for these categories was the opinion article. In terms of themes, 'Islamophobia' stood out with respect to Islamism 
(17.8\%), Arab Spring (14\%), international politics (12.9\%) and conflicts (12.1\%), practically the same themes as for 'Islamophilia' but with very different percentages: first, Arab Spring (28.2\%), followed by international politics (18.2\%) and Islamism (13.6\%).

\section{Conclusions and discussion}

From 2011 to 2013, the Spanish press heavily covered the Egyptian situation as evidenced by the 3,045 news stories published, references on the front-pages (8.8\%), and a high number of columns (18.5\%) and editorials (4.2\%). Therefore, the Egyptian revolution exemplifies the cross-border nature of journalism and the existence of a 'global village', since an international event that had minimal impact on Spanish politics and society-beyond economic and tourism issues, two superficial elements in the coverage-became a matter of periodic relevance. In other words, the Egyptian case reliably reflects the domestication of foreign news, as Fornaciari (2011) maintains.

It cannot be confirmed that during the coverage of the Egyptian revolution the schemes in the media representation of the Arab-Islamic issue that we set in the literature review were broken, but the coverage did provide more light than shadow. One of the limitations of this research is that it would have to be complemented with other approaches such as discourse analysis to delve deeper into nuances. However, it can be concluded that the 'Islamophobic' narrative was hardly present or that the reproduction of stereotypes in pictures was practically non-existent. For this reason, after weighing all aspects of the Arab-Islamic discourse (both cultural and religious), it can be concluded that the coverage was much closer to reality than to sensationalism, 'Islamophobia' or Orientalism, that is, to clichés, stereotypes, and prejudices. It is only necessary to insist that there were practically the same levels of 'Islamophobia' and 'Islamophilia'.

Obviously, Islam and Islamism had to be important aspects of the coverage, but their representation was fair and adequate, as was the case with the coverage of democracy, Israel, or the Copts. Indeed, it had initially been expected that there would be more religious bias and that both Islam and the Copts would have greater prominence in the articles. It must not be forgotten that two Spanish newspapers, $A B C$ and La Vanguardia, have strong links with Catholicism, as Jiménez-Yáñez (2019) and Durán (2019) have demonstrated. In fact, it was La Vanguardia that mentioned Islam the least. For its part, $A B C$ stands out with respect to references to Copts, negative evaluations of themes, or reproduction of 'Islamophobic' narratives, present in its coverage in approximately one out of every four 
cases. True to its progressive orientation, El País distanced itself more than any other newspaper from 'Islamophobia', expressing a high degree of 'Islamophilia'. It also had the most mentions of democracy and Islam. Finally, El Mundo distinguished itself as being more 'Islamophobic' in the first stages of the Egyptian revolution and more 'Islamophobic' in its last stage, the coup d'état. In addition, it was the outlet that most referred to opposition leader Mohamed El Baradei and the one that, after El País, had the most mentions of democracy, two facts that confirm its pro-revolutionary character.

Future research will have to corroborate the scope of these findings by analyzing Arab-Islamic issues from a domestic viewpoint (immigration, establishment of mosques, Ceuta and Melilla, etc.), contrasting them with other countries to determine if the Spanish case is isolated and can be explained by its history or as part of other international matters such as conflicts, wars, terrorism, or crises such as the refugee issue. In addition, to better determine which ideas are co-occurring with 'Islamophobia', it would be convenient to further extend the frame analysis, for example, building on the eight perspectives of the Runnymede Trust. Similarly, rounding off this study with a qualitative approach would make it possible to better study both the discourse and the roots of this phenomenon. Of course, delving deeper into the impact of the articles on the readers or on the news production process itself is a possibility that should not be discarded.

\section{References}

Abdelkefi, M. (1994). Los políticos árabes y su imagen en los medios [The image of Arab politicians in the media]. In J. Bodas Barea, \& T. Drago (Eds.), El Mundo Árabe y su imagen en los medios (pp. 270-278). Madrid: Comunica.

Ahmed, S., \& Matthes, J. (2016). Media representation of Muslims and Islam from 2000 to 2015: A meta-analysis. International Communication Gazette, 79(3), 219-244.

Alasuutari, P., Qadir A., \& Creutz, K. (2013). The domestication of foreign news: News stories related to the 2011 Egyptian revolution in British, Finnish and Pakistani newspapers. Media, Culture \& Society, 35(6), 692-707.

Al Aswany, A. (2011). Egipto: las claves de una revolución inevitable [Egypt: The keys to an inevitable revolution]. Barcelona: Galaxia Gutenberg.

Alba Rico, S. (2015). Islamofobia. Nosotros, los otros, el miedo [Islamophobia: Us, the others, the fear]. Barcelona: Icaria.

Algora Weber, M. D. (2003). La cuestión palestina en el régimen de Franco [The Palestinian issue during the Franco regime]. In I. Álvarez Ossorio, \& I. Barreñada (Eds), España y la cuestión palestina (pp. 19-50). Madrid: La Catarata.

Algora Weber, M. D. (2011). La política exterior española y la política internacional: efectos sobre las relaciones hispano-árabes en la historia contemporánea [The Spanish 
foreign policies and international politics: Effects on the Spanish-Arab relationships in contemporary history]. In B. López García, \& M. Hernando De Larramendia (Eds.), España, el Mediterráneo y el mundo arabomusulmán (pp. 57-80). Girona: Icaria-IEMed.

Allen, C. (2010). Islamophobia. Burlington: Ashgate Publishing Limited.

Al Maskati, N. A. (2012). Newspaper coverage of the 2011 protests in Egypt. International Communication Gazette, 74(4), 342-366.

Almodóvar, M. (2015). Egipto tras la barricada [Egypt behind the barricade]. Barcelona: Virus.

Anderson, L. (2015). Countering Islamophobic media representations: The potential role of peace journalism. Global Media and Communication, 11(3), 255-370.

Armañanzas, E., \& Díaz Noci, J. (1996). Periodismo y argumentación: géneros de opinion [Journalism and argumentation: Opinion genres]. Bilbao: Universidad del País Vasco.

Awad, A. F. (2006). Las relaciones culturales entre Egipto y España [The cultural relations between Egypt and Spain]. Hesperia, Culturas del Mediterráneo, 4, 147-156.

Azaola Piazza, B. (2008). Historia del Egipto contemporáneo [History of contemporary Egypt]. Madrid: Catarata.

Azaola Piazza, B., \& González González, I. (2012). Estudios de caso de la política exterior española hacia el Mundo Árabe y Musulmán: Egipto [Case studies of the Spanish foreign policy towards the Arab and Muslim world: Egypt]. Revista de Estudios Internacionales Mediterráneos, 12, 147-156.

Balta, P. (1994). Los medios y los malentendidos euroárabes. [The media and the Euro-Arab misunderstandings]. In J. Bodas Barea, \& T. Drago (Eds.), El Mundo Árabe y su imagen en los medios (pp. 29-45). Madrid: Comunica.

Barrera, C. (1995). Sin mordaza. Veinte años de prensa en democracia [Without gag: Twenty years of press in a democracy]. Madrid: Temas de hoy.

Beck, L. (2012). 'Moros en la costa': Islam in Spanish visual and media culture. Historia Actual Online, 29, 93-106.

Bensalah, M. (2006). Islam y representaciones mediáticas [Islam and mediated representations]. Revista CIDOB d'Afers Internacionals, 73-74, 69-83.

Bodas Barea, J., \& Drago, T. (1994). El Mundo Árabe y su imagen en los medios [The Arab world and its image in the media]. Madrid: Comunica.

Bravo López, F. (2011). Towards a definition of Islamophobia: Approximations of the early twentieth century. Ethnic and Racial Studies, 34(4), 556-573.

Canel, M. J. (1999). El País, ABC y El Mundo. Tres manchetas, tres enfoques de las noticias [Three editorials, three news foci]. Zer, 6, 97-117.

Casani Herranz, A. (2016): Islamophobia in Spain. National Report 2015. In E. Bayraklı, \& F. Hafez (Eds.), European Islamophobia Report 2015 (pp. 467-490). Istanbul: SETA.

Castells, M. (2012). Networks of outrage and hope: Social movements in the internet age. Cambridge: Polity Press

Cesari, J. (2011). Islamophobia in the West: A comparison between Europe and the United States. In J. Esposito, \& I. Kalin (Eds.), Islamophobia: The challenge of pluralism in the $21^{\text {st }}$ century (pp. 21-43). New York: Oxford University Press.

Clarke, K. (2013). Aish, Huriyya, Karama Insaniyya: Framing and the 2011 Egyptian uprising. European Political Science, 12(2), 197-214.

Córdoba Hernández, A. M. (2011). El conflicto palestino-israelí visto desde España: oscilaciones y tendencias de la opinión pública [The Palastine-Israel conflict seen from Spain: Oscillations and tendencies of public opinion]. Ámbitos, 20, 149-174. 
Córdoba Hernández, A. M. (2015). La fotografía y el texto en la construcción del 'framing’ de la Primavera Árabe: un análisis del cubrimiento y tratamiento informativo de la prensa de referencia Colombiana, en 2011 [Photography and text in the construction of 'framing' of the Arab Spring: An analysis of the press coverage in 2011]. Observatorio (Obs*), 9(2), 149-172.

Corpas, M. A. (2010). Las comunidades islámicas en la España actual (1960-2008). Génesis e institucionalización de una minoría de referencia [The Islamic communities in contemporary Spain (1960-2008)]. Madrid: UNED.

Corral-García, A., \& Fernández Romero, C. (2015). ‘Framing’ y mundo árabe: la cobertura de la prensa española en torno a la revolución tunecina ['Framing' and Arab World: the Spanish Press Coverage in the Tunisian Revolution]. Estudios sobre el Mensaje Periodístico, 21(2), 793-811.

Cottle, S. (2011). Media and Arab uprisings of 2011: Research notes. Journalism, 12(5), 647-659.

d'Haenens, L., \& Bink, S. (2006). Islam in the Dutch press: with special attention to the 'Algemeen Dagblad'. Media, Culture \& Society, 29(1), 135-149.

Drago, T. (1994). Pautas y estrategias en la información sobre el Mundo Árabe [Rules and strategies in the information about the Arab world]. In J. Bodas Barea, \& T. Drago (Eds.), El Mundo Árabe y su imagen en los medios (pp. 16-27). Madrid: Comunica.

Durán, R. (2019). El encuadre del islam y los musulmanes: la cobertura periodística en España [The picture of Islam and the Muslims: The media coverage in Spain]. Revista de Estudios Internacionales Mediterráneos, 26, 156-181.

Elahi, F., \& Khan, O. (2017). Introduction: What is Islamophobia? In F. Elahi, \& O. Khan (Eds.), Islamophobia: Still a challenge for us all (pp. 5-12). London: Runnymede Trust.

Elena, M. (2015). El posicionamiento de medios internacionales ante los movimientos sociales: CNN y Al-Jazeera English en la caída de Morsi [The positioning of the international media towards social movements: CNN and Al-Jazeera English on the fall of Morsi]. Communication \& Society, 29(3), 119-131.

El-Madkouri, M. (2006). El Otro entre Nosotros: el musulmán en la prensa [The other in our midst: The Muslim in the press]. In M. Lario Bastida (Ed.), Medios de comunicación e inmigración (pp. 97-123). Murcia: Convivir sin racismo, Programa CAM.

Fornaciari, F. (2011). Framing the Egyptian Revolution: A content analysis of Al Jazeera English and the BBC. Journal of Arab \& Muslim Media Research, 4(2-3), 223-235.

Frissen, T., Ichau, E., Boghe, K., \& d'Haenens, L. (2017). \#Muslim? Instagram, Visual Culture and the Mediatization of Muslim Religiosity: Explorative analysis of visual and semantic content on Instagram. In M. Kayiki, \& L. d'Haenens (Eds.), European Muslims and New Media (pp. 141-169). Leuven: Leuven University Press.

García Gordillo, M. M. (2004). Mecanismos de creación de héroes y antihéroes para la opinión pública internacional en periodos de Guerra [Mechanisms of the creation of heroes and antiheroes for the international public opinion in war times]. Ámbitos, 11-12, 39-76.

Gelvin, J. L. (2013). Conclusion: The Arab world at the intersection of the national and transnational. In M. L. Haas, \& D. W. Lesch (Eds.), The Arab Spring. Change and resistance in the Middle East (pp. 238-255). Boulder: Westview Press.

Golan, G. (2013). The gates of op-ed diplomacy: Newspaper framing the 2011 Egyptian revolution. The International Communication Gazette, 75(34), 359-373.

González Alcantud, J. A. (2002). Lo moro. Las lógicas de la derrota y la formación del estereotipo islámico [The moor. The logics of defeat and the formation of the Islamic stereotype]. Barcelona: Anthropos. 
González del Miño, P. (2014). Egipto: desafíos de una transición incierta [Egypt: Challenges of an insecure transition]. In P. González del Miño (Ed.), Tres años de revoluciones árabes (pp. 140-168). Madrid: Catarata.

Hafez, K. (2000). The West and Islam in the mass media: Cornerstones for a new international culture of communication in the $21^{\text {st }}$ century (Discussion paper). Bonn: Zentrum für Europäische Integrationsforschung.

Hafez, K. (2016). Discurso islamófobo en los medios de comunicación [Islamophobe discourse in the communication media]. Afkar Ideas, 50, 23-26.

Halliday, F. (1999) 'Islamophobia' reconsidered. Ethnic and Racial Studies, 22(5), 892-902.

Halverson, J. R., Ruston, S. W., \& Trethewey, A. (2013). Mediated martyrs of the Arab Spring: New media, civil religion, and narrative in Tunisia and Egypt. Journal of Communication, 63(2), 312-332.

Hernández Guerrero, M. J. (2012). La traducción al servicio de una línea editorial: la primavera árabe en el diario El País [The service-oriented translation of an editorial line: The Arab Spring and the paper El País]. Meta. Translators' Journal, 57(4), 960-976.

Huntington, S. P. (1993). The clash of civilizations? Foreign Affairs, 72, 22-43.

Huntington, S. P. (1996). The clash of civilizations and the remaking of world order. New York: Simon \& Schuster.

Ibrahim, D. (2010). The framing of Islam on network news following the September $11^{\text {th }}$ Attacks. International Communication Gazette, 72(1), 111-125.

Ichau, E., \& d'Haenens, L. (2016). The Representation of Islam and Muslims in Flemish TV news. In S. Mertens, \& H. De Smaele (Eds.), Representations of Islam in the News: $A$ Cross-Cultural Analysis (pp. 91-108). London: Lexington Books.

Jiménez-Yáñez, R. M. (2019). Análisis de los editoriales sobre una polémica visita papal [Analysis of the editorials about a polemic papal visit]. ONOMÁZEIN, 44, 63-84.

Karvala, D. (2016). FAQ contra la islamophobia [FAQ against Islamophobia]. In D. Karvala, (Ed.), Combatir la islamofobia. Una guía antirracista (pp. 117-138). Barcelona: Icaria.

Khader, B. (2016). Reflexiones sobre la islamofobia 'ordinaria' [Reflections of the 'normal' Islamophobia]. Afkar Ideas, 50, 16-18.

Kumar, D. (2010). Framing Islam: The resurgence of orientalism during the Bush II era. Journal of Communication Inquiry, 34(3), 254-277.

Kumar, D. (2018). The right kind of “Islam”. Journalism Studies, 19(8), 1079-1097.

León, B. (2005). Prólogo [Prologue]. In E. Said, Cubriendo el islam. Cómo los medios de comunicación y los expertos determinan nuestra visión del resto del mundo (pp. 13-31). Barcelona: Debate.

Lewis, B. (1990). The roots of Muslim rage. The Atlantic Monthly, 266(3), 47-60.

Lim, M. (2013). Framing Bouazizi: 'White lies', hybrid network, and collective/connective action in the 2010-11 Tunisian uprising. Journalism, 14(7), 921-941.

López, P., Otero, M., Pardo, M., \& Vicente, M. (2010). La imagen del mundo árabe y musulmán en la prensa española [The image of the Arab and Muslim world in the Spanish press]. Sevilla: Fundación Tres Culturas.

López García, B. (2013). España y el mundo árabe-islámico: historia de una multiplicidad de relaciones y encuentros [Spain and the Arab-Islamic world: History of a multitude of relationships and encounters]. In 0. Orozco de la Torre, \& G. Alonso García (Eds.), El Islam y los musulmanes hoy: Dimensión internacional y relaciones con España (pp. 11-28). Madrid: Escuela Diplomática \& Casa Árabe. 
López García, B. (2014). Prólogo [Prologue]. In P. González del Miño (Ed.), Tres años de revoluciones árabes [Three years of Arab revolutions] (pp. 15-23). Madrid: Catarata.

Louassini, Z. (2003). La imagen del árabe en los medios de comunicación occidentales (y II)

[The image of the Arab in the Western communication media]. MEAH, Sección árabe-islam, $52,125-146$.

Luqiu, L. R., \& Young, F. (2018). Islamophobia in China: News coverage, stereotypes, and Chinese Muslims' perceptions of themselves and Islam. Asian Journal of Communication, 28(6), 598-619.

Luyendijk, J. (2013). Hello Everybody. Imágenes de Oriente Medio [Images of the Middle East]. Barcelona: Península.

Lynch, M. (2012). The Arab uprising: The unfinished revolutions of the new Middle East. New York: Public Affairs.

Martin, P., \& Phelan, S. (2002). Representing Islam in the wake of September 11: A comparison of US television and CNN online message board discourses. Prometheus, 20(3), 263-269.

Martín Corrales, E. (2004). Maurofobia/islamofobia y maurofilia/islamofilia en la España del siglo XXI [Maurophobia/Islamophobia and Maurophilia/Islamophilia in Spain in the $21^{\text {st }}$ century]. Revista CIDOB d'Afers Internacionals, 66-67, 39-51.

Martín Muñoz, G. (2007). Musulmanes en Europa, entre Islam e Islamofobia [Muslims in Europe, between Islam and Islamophobia]. In Casa Árabe (Ed.), Musulmanes en la Unión Europea: discriminación e islamofobia (pp. 7-9). Madrid: Casa Árabe.

Martín Muñoz, G. (2010). Unconscious Islamophobia. Human Architecture: Journal of the Sociology of Self-Knowledge, 8(2), 21-28.

Mertens, S., \& d'Haenens, L. (2013). Cultural Values in Press Reporting on Islam: The UK and Flanders Compared. Australian Journalism Review, 35(2), 35-45.

Modood, T., Triandafyllidou, A., \& Zapata-Barrero, R. (2006). Multiculturalism, Muslim and Citizenship: A European Approach. London and New York: Routledge.

Moreno Espinosa, P. (2000). Los géneros periodísticos informativos en la actualidad internacional [The journalistic genres in today's internationality]. Ámbitos, 5(2), 169-190.

Ortega Marín, J. (1994). Imágenes árabes en la prensa Española [Arab images in the Spanish press]. In J. Bodas Barea, \& T. Drago (Eds.), El Mundo Árabe y su imagen en los medios (pp. 250-258). Madrid: Comunica.

Piquer Martí, S. (2015). La islamofobia en la prensa escrita española: aproximación al discurso periodístico de El País y La Razón [Islamophobia in the Spanish press: Approaching a journalistic discourse of El País and La Razón]. Dirāsāt Hispānicas, 2, 137-156.

Poole, E. (2002). Reporting Islam: Media representations of British Muslims. London: IB Tauris.

Powell, K. A. (2011). Framing Islam: An analysis of U.S. media coverage of terrorism since 9/11. Communication Studies, 62(1), 90-112.

Ramberg, I. (2004). Islamophobia and its consequences on young people. Budapest: Council of Europe.

Rana, J. (2007). The story of Islamophobia. Souls, 9(2), 148-161.

Rane, H., Ewart, J., \& Martinkus, J. (2014). Media framing of the Muslim world. Conflicts, crises and contexts. New York: Palgrave Macmillan.

Rane, H., \& Salem, S. (2011). Social media, social movements and the diffusion of ideas in the Arab uprisings. Journal of International Communication, 18(1), 97-111. 
Reig, R. (2000). Medios de comunicación y poder en España: prensa, radio, televisión y mundo editorial [Communication media and power in Spain: Press, radio, TV, and editorial world]. Barcelona: Paidós.

Requena, P. (2012). El tiempo robado [The stolen time]. In M. Ayestarán et al. (Eds.), Queremos saber. Cómo y por qué la crisis del periodismo nos afecta a todos (pp. 41-65). Barcelona: Debate.

Reza, S. M. (2011). Representations of Islam and Muslims in press coverage. World Journal of Islamic History and Civilization, 1(4), 234-241.

Richardson, J. E. (2004). (Mis)Representing Islam: The racism and rhetoric of the broadsheet press. Amsterdam: John Benjamins.

Rodríguez, O. (2012). Yo muero hoy. Las revueltas en el mundo árabe [l'll die today. The revolts in the Arab world]. Barcelona: Debate.

Rogan, E. (2011). The Arabs: A history. New York: Basic Books.

Runnymede Trust (1997). Islamophobia: A challenge for us all. London: Runnymede Trust.

Said, E. W. (1978). Orientalism. London: Penguin Books.

Said, E. W. (1981). Covering Islam: How the media and the experts determine how we see the rest of the world. New York: Pantheon.

Sardar, Z. (2009). Extraño Oriente. Prejuicios, mitos y errores acerca del Islam [Strange orient: Prejudices, myths, and misapprehensions around Islam]. Barcelona: Gedisa.

Segura, A. (2004). Señores y vasallos del siglo XXI. Una explicación de los conflictos internacionales [Monarchs and vassals of the $21^{\text {st }}$ century: An explanation of the international conflicts]. Madrid: Alianza.

Serrano, P. (2009). Desinformación. Cómo los medios ocultan el mundo [Disinformation. How the media obscure the world]. Barcelona: Península.

Shaw, I. S. (2012). Stereotypical representations of Muslims and Islam following the 7/7 London terror attacks: Implications for intercultural communication and terrorism prevention. International Communication Gazette, 74(6), 509-524.

Shelton, C., Cleven, E., \& Hoffman, A. M. (2019). Deadly foreign terrorism and the rank-ordered tournament for foreign press attention: Implications for counterterrorism. International Interactions, 45(2), 344-368.

Soler i Lecha, E. (2013). Cuando las crisis se superponen: Europa y España ante la Primavera Árabe [When the crises take them over: Europe and Spain in the light of the Arab Spring]. In Fundación Seminario de Investigación para la Paz (Ed.), El Mundo Árabe en la encrucijada (pp. 391-402). Zaragoza: Mira Editores.

Taibi, M., \& El-Madkouri, M. (2006). Estrategias discursivas en la representación del Otro árabe [Discursive strategies in the representation of the Arab Other]. In M. Lario Bastida (Ed.), Medios de comunicación e inmigración (pp. 125-143). Murcia: Convivir sin racismo, Programa CAM.

Tortosa, J. M. (1999). El islam ¿enemigo de Occidente? [Islam, enemy of the West?] Papers, 57, 75-88.

Valenzuela, J. (2013). ¿Y si resulta que los árabes también son humanos? [And in case it comes out that Arabs, too, are humans?] In J. Luyendijk, Hello Everybody. Imágenes de Oriente Medio (pp. 15-21). Barcelona: Península.

Van Dijk, T. (2008). Racismo, prensa e Islam [Racism, press, and Islam]. Derechos Humanos, 5 , 18-20.

Zahedi, F. (2014). La cultura de la posmodernidad y la Primavera Árabe [The culture of postmodernity and the Arab Spring]. In J. Guillamet, \& F. Salgado (Eds.), El Periodismo en las 
transiciones políticas. De la Revolución Portuguesa y la Transición Española a la Primavera Árabe (pp. 323-333). Madrid: Biblioteca Nueva.

Zugasti, R. (2007). La forja de una complicidad. Monarquía y prensa en la Transición española (1975-1978) [The forge of a complicity. Monarchy and press in the Spanish Transition (1975-1978)]. Madrid: Fragua. 